\title{
Effective Approaches of Potential Bioagent, Phytoextract, Fungicide and Cultural Practice for Management of Banana Fruit Rot Disease
}

\section{Kedar Nath ${ }^{1 *}$, Solanky KU1 and Kumawat $\mathrm{GL}^{2}$}

${ }^{1}$ Department of Plant Pathology, N.M. College of Agriculture, Navsari Agricultural University, Navsari-645039, India

${ }^{2}$ Division of Floriculture \& Landscaping, Indian Agricultural Research Institute, Pusa, New Delhi-110 012, India

\begin{abstract}
Banana fruit rot caused by Lasiodiplodia theobromae (Pat.) Griffth and Maubl. is an important emerging disease in South Gujarat region. It was frequently and abundantly isolated from finger rot in field and post-harvest fruit rot disease in markets as well storage house. Integrated disease management approaches would be an important for the management of post-harvest banana fruit rot disease. Four fungicides such as carbendazim and propiconazole @ 250 ppm, carbendazim 12\%+mancozeb 63\% @1500 ppm and mancozeb @ 2500 ppm completely inhibited the mycelial growth of $L$. theobromae and proved statistically superior over the rest of fungicides tested. Copper oxychloride stimulated the growth of $L$. theobromae. Two extracts such as garlic clove and cinnamon leaf extract at $10 \%$ concentration inhibited the mycelial growth of $L$. theobromae by 47.09 and $33.86 \%$ respectively. Five known bioagent tested by dual culture technique showed that Pseudomonas fluorescens and Bacillus subtilis were strong antagonism to $L$. theobromae by inhibiting mycelial growth up to $75.83 \%$ and $70.50 \%$ respectively. The results of field experiment showed that single spray of carbendazim @ $0.5 \mathrm{gL}^{-1}$, propiconazole @1 $\mathrm{mLL}^{-1}$, garlic clove and cinnamon leaf extract @100 mlL-1 water, Pseudomonas fluorescens and Bacillus subtilis@1 × $107 \mathrm{CFUml}^{-1}$ and bunch covered with blue polythene exhibited greater control efficacy to banana finger rot disease in field condition. The fruits harvested from treated plant kept for natural ripening, cent percent fruit rot disease control was observed in propiconazole treated fruit under storage condition up to eating ripe stage.
\end{abstract}

Keywords: Banana fruits, Lasiodiplodia theobromae, carbendazim, propiconazole, Pseudomonas fluorescens, Bacillus subtilis and LLDPE

\section{Introduction}

Banana (Musa paradisiaca L.) fruit is one of the most important commercial fruit and vegetable crops grown all over the world in the tropical and subtropical areas. It is the second largest fruit crop, belongs to family Musaceae in order Scitamineae. It is cultivated on an area of $4.81 \mathrm{M}$ ha with an average production of $100.9 \mathrm{MT}$. in world; India produced $25.6 \%$ of total banana production of the world during 201213 [1]. It shared 32.6 per cent of total national fruit production during 2012-13 [2]. It ranks third in terms of area and first in production with a second in productivity of $34.2 \mathrm{mt} / \mathrm{ha}$ [2]. Gujarat shares 17.1 percent of total national banana production with highest productivity $(62.3$ t/ha.). The cultivated banana is susceptible to many diseases, mostly fungal pathogen which attacks various part of the plant from root to fruit. Bananas are highly perishable commodities with post-harvest losses estimated to the tune of $25-30 \%$ [3]. Banana fruit suffers from many serious post-harvest diseases such as fruit rot, crown rot, finger rot, cigar-end rot and pitting disease. The most important disease problem of bananas is finger rot as well as fruit rot in field and storage condition under south Gujarat region. Finger rot diseases may involve several fungal species, but the most commonly associated organism is L. theobromae [4-6] Lasiodiplodia theobromae (Syn: Botryodiplodia theobromae) is a causative fungus of mango dieback disease reported by Khanzada et al. [7]. Crown rot and fruit rot are the most severe post-harvest disease of banana. It is caused by a complex of fungi viz., Colletotrichum musae (Berk. and Curt.), Fusarium moniliformae Sheld., Fusarium pallidoroseum (Cooke) Sacc., Nigrospora sphaerica (Sacc.) Mason and Botryodiplodia theobromae Pat. are implicated with pathogenicity in the Windward Islands [8-11]. In the genus Lasiodiplodia, L. theobromae, is geographically widespread but is most common in the tropics and subtropics regions which is associated approximately with 500 hosts [12]. Complete inhibition of mycelial growth of $L$. theobromae causing mango fruit rot by carbendazim [13-15] Aqueous garlic clove extract at 30 and $50 \mathrm{mlL}^{-1}$ concentration completely inhibited the mycelial growth of $\mathrm{B}$. theobromae, while 10 $\mathrm{mlL}^{-1}$ concentration inhibited the conidial germination of the pathogen observed by Andrade et al. [16]. Bacillus subtilis can be used as potential bio-control agent against the $\mathrm{B}$. theobromae $[17,18]$. Control of banana anthracnose caused by Colletotrichum musae through deflowering and bunch covering at horizontal fingers stage (Hfing) is also effective. Fruit contamination rate was significantly higher on late-covered bunches (Hfing +7 days, Hfing+14 days) and highest in uncovered bunches reported by Bedimo et al. [19].

The current postharvest problems for bananas are mainly concerned with storage and marketing. It is necessary to identify the pathogen causing above said diseases and ultimately to reduce the yield loss of the banana fruit. The aim of this investigation is to present the latest information on the management of banana fruit rot diseases based on integration of field and postharvest studies, including cultural practices, phytochemicals, bioagents and fungicides in relation to banana fruit rot disease and its self-life.

*Corresponding author: Kedar Nath, Department of Plant Pathology, N.M College of Agriculture, Navsari Agricultural University, Navsari-645039, India, Tel: +918511163620; E-mail: drkdkushwaha@nau.in

Received August 19, 2014; Accepted November 25, 2014; Published November 29,2014

Citation: Nath K, Solanky KU, Kumawat GL (2014) Effective Approaches of Potential Bioagent, Phytoextract, Fungicide and Cultural Practice for Management of Banana Fruit Rot Disease. J Plant Pathol Microb 5: 246 doi:10.4172/2157-7471.1000246

Copyright: (c) 2014 Nath K, et al. This is an open-access article distributed under the terms of the Creative Commons Attribution License, which permits unrestricted use, distribution, and reproduction in any medium, provided the original author and source are credited. 
Citation: Nath K, Solanky KU, Kumawat GL (2014) Effective Approaches of Potential Bioagent, Phytoextract, Fungicide and Cultural Practice for Management of Banana Fruit Rot Disease. J Plant Pathol Microb 5: 246. doi:10.4172/2157-7471.1000246

Page 2 of 8

\section{Materials and Methods}

\section{Fungal isolation and pathogenicity test}

Immature banana fruit commonly known as finger, mature and ripe fruits of banana variety "Grand naine" showing finger and fruit rot symptoms were collected from domestic store-rooms of South Gujarat (viz., Navsari, Gandevi, Surat, Bardoli and Vyara) and field of "Soil and Water Management Project, Department of Plant Pathology and Fruit Research Station Gandevi". The banana fingers and fruits were surface disinfected with $2 \%$ sodium hypochloride for 2 minutes and then three time rinsed with tap water, and air-dried. The disinfected fingers and fruits were stored in the laboratory in separate polythene bag containing a wet cotton piece at room temperature $\left(25-28^{\circ} \mathrm{C}\right)$. The development of different rots was visually examined for fungal appearance. The infected tissue from banana fruit rot were cut into small bits of 3-5 mm in size, surface sterilized in a $2 \%$ sodium hypochlorite solution for a minutes and then washed three time in sterile distilled water. They were subsequently transferred on sterile Potato Dextrose Agar (PDA) medium plates under aseptic conditions and incubated at $27 \pm 1^{\circ} \mathrm{C}$. Fungal colonies that appeared were subcultured and identified according to the key of "Illustrated Genera of Imperfect Fungi" described by Barnett and Hunters [20]. They were then identified accordingly.

The pathogenic ability of the isolated fungi was performed under laboratory conditions. Two hands of banana containing about 10 fingers/ fruits in each were surface disinfected with $2 \%$ sodium hypochlorite for $2 \mathrm{~min}$, then 3 times rinsed with tap water, and airdried, then artificially inoculated individually with each isolated fungal pathogens by pin-prink method on each freshly exposed fingertip tissue and mature fruits near the crown portion. Another set was treated with sterile distilled water served as control. Two hands of banana fruit contained ten fruits in each for each fungus treatment were used. The inoculated banana fruits were kept separately in a polythene bag containing a wet cotton piece at room temperature for 8-10 days and then examined for signs and symptoms of fruit rot. The percent disease index was calculated as a portion of infected fingers/ fruits relative to the whole fingers/fruits in each banana hand (Figure 1a and $1 b$ ).

\section{In vitro evaluation of fungicides against $L$. theobromae}

The antifungal activity of seven different fungicides evaluated, in these, three non- systemic (viz.,mancozeb, copper oxychloride, chlorothalonil) @1500, 2000, 2500 ppm, three systemic (viz., carbendazim, propiconazole, hexaconazole)@ 250, 500, 1000 ppm and one combination (carbendazim 12\%+mancozeb 63\%, @1500, 2000, $2500 \mathrm{ppm}$ were tested against most frequently isolated fungus pathogen viz., L. theobhomae in vitro by poisoned food technique [21].

The measured quantities of fungicides were incorporated in the melted sterilized PDA medium aseptically to obtain desired concentration (Minimum Inhibitory Concentrations, MICs) of different fungicides at the time of pouring into borosil glass petri plates $(\varnothing 90 \mathrm{~mm})$. The $60 \mathrm{ml}$ medium with fungicide was shaken well to give uniform dispersal of fungicides. Then the $20 \mathrm{ml}$ medium with fungicides was poured in each of the Petri plates. After solidification, $5 \mathrm{~mm}$ discs of 7 days old culture of $L$. theobromae was placed in the center of test plates and arranged in completely randomized design with three repetitions. The plates were incubated at $27 \pm 1^{\circ} \mathrm{C}$. The plates without fungicides served as control. After 48 and $72 \mathrm{hrs}$ of incubation, diameter of fungal growth was measured in each case, by averaging two diameter of fungal colony at right angle to one another and the per cent inhibition was calculated by following formula [22].

\section{$\mathrm{PGI}=(\mathrm{C}-\mathrm{T}) / \mathrm{C} \times 100$}

Where; PGI=Per Cent Growth Inhibition, $\mathrm{C}=$ Colony Diameter In Control (mm), $\mathrm{T}=$ Colony Diameter In Treatment $(\mathrm{mm})$

\section{In vitro evaluation of phytoextract against $L$. theobromae}

The inhibitory effect of Acalypha (Acalypha indica L.), Barmasi (Catharanthus roseus L.), Garlic (Allium sativum L.), Turmeric (Curcuma longa L.), Lantana (Lantana camara L.), Neem (Azadirachta indica Juss.), Black Tulsi (Ocimum basilcum L.), Babul (Acacia nilotica L.), Eucalyptus (Eucalyptus citriodora Hoch.), Aloevera (Aloe barbadensis L.), Cinnamon (Cinnamomum zeylanicum L.) and Ardusi (Adhatoda vasica Ness.) were evaluated against growth of L. theoberomae under in vitro condition by poisoned food technique.

\section{Method of Extraction preparation [23]}

The fresh and healthy leaves/ bulb/ rhizome were brought to laboratory and thoroughly washed with tap water and then surface sterilized with $2 \%$ sodium hypochloride solution for 5 minutes, then rinsed with sterilized distilled water, and air-dried and kept in sterilized beaker. $100 \mathrm{~g}$ air dried plant part was crushed in grinder mixture (Sumeet) by adding $100 \mathrm{ml}$ of sterilized distilled water. The phytoextracts thus obtained were then filtered through double layered sterilized muslin cloth and filterate was centrifuged at 10,000 rpm for 10 minutes and the clear extract was collected in sterilized conical flask. The clear extracts were made to volume of $1: 1(\mathrm{w} / \mathrm{v})$. The flasks were
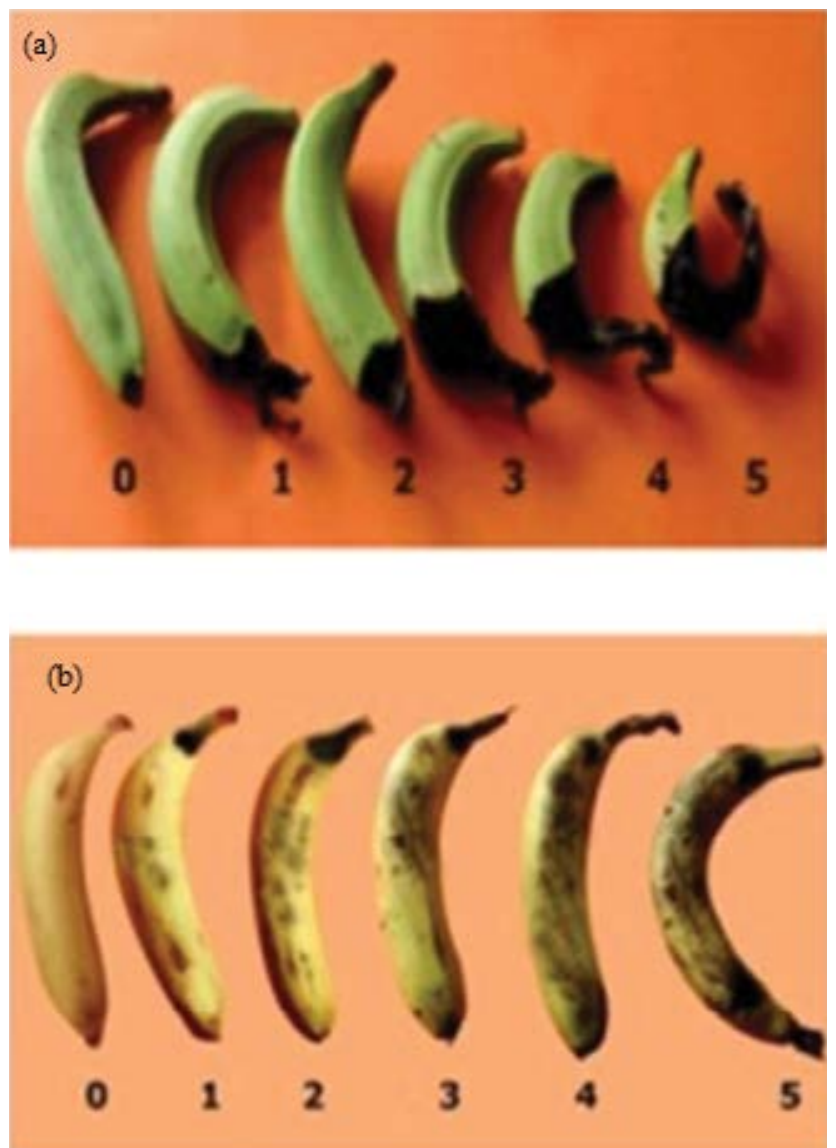

Figure 1: (a) Assessment key for banana finger rot disease. (b) Assessment key for banana fruit rot (ripe) disease. 
labeled and stored in refrigerator for further use. This was considered as 100 per cent concentration for the study of efficacy of plant extract. Two different concentrations 5 and 10 per cent were used to study the inhibitory effect on growth of L. theobramae by using "poisoned food technique" [24].

$100 \mathrm{ml}$ of PDA was taken in flasks of $250 \mathrm{ml}$ capacity, plugged and sterilized by autoclaving at $121^{\circ} \mathrm{C}$ temperature $\left(1.2 \mathrm{~kg} / \mathrm{cm}^{2}\right)$ for 20 minutes. After autoclaving and cooling to about $45^{\circ} \mathrm{C}, 5 \mathrm{ml}$ and 10 $\mathrm{ml}$ of the respective phytoextracts were mixed thoroughly in the flasks containing $100 \mathrm{ml}$ of PDA medium. Medium without phytoextracts served as control. $20 \mathrm{ml}$ of media was poured in each sterilized Petri plate under aseptic conditions. After solidification, $5 \mathrm{~mm}$ discs of 7 days old culture of $L$. theobromae was placed in the centre of test plates and arranged in completely randomized design with three repetitions. The plates were incubated at $27 \pm 2^{\circ} \mathrm{C}$ temperature. The observation on mycelial growth was measured by averaging two diameters of colony at right angle to one another at 24 hour interval and per cent growth inhibition (PGI) was calculated using following formula [25].

\section{$\mathrm{PGI}=(\mathrm{C}-\mathrm{T}) / \mathrm{C} \times 100$}

Where, PGI=Per Cent Growth Inhibition, C=Colony Diameter In Control (mm),

\section{$\mathrm{T}=$ Colony Diameter In Treatment $(\mathrm{mm})$}

\section{In vitro effect of bioagents on growth of $L$. theobromae}

Five known bioagent viz., Trichoderma viride Pers (IARI, New Delhi, isolate), Trichoderma harzianum Rifai (Junagadh, Gujarat, isolate), Trichoderma longibrachyatum Rifai (IARI, New Delhi, isolate), Bacillus subtilis (Anand, Gujarat, isolate) and Pseudomonas fluorescens (Junagadh, Gujarat, isolate) were bio-assayed for antibiosis on PDA plates against the L. theobromae by Dual culture technique.

The test antagonist and L. theobromae were grown on PDA and from 6 days old culture of respective antagonist and pathogen, $4 \mathrm{~mm}$ diameter disc of the test organism was cut aseptically and placed at one end of the Petri plate containing $20 \mathrm{ml}$ PDA. In the opposite end a similar disc of the pathogen was aseptically placed by Dual culture technique [26].

Three repetition of each treatment were maintained and the plate with only pathogen served as control. The plates were incubated at $27 \pm$ $1^{\circ} \mathrm{C}$ and after seven days of incubation, mycelial growth $L$. theobromae was measured. Per cent growth inhibition of the pathogen in each treatment in comparison to control was calculated by the following formula [27].

\section{$\mathrm{PGI}=(\mathrm{C}-\mathrm{T}) / \mathrm{C} \times 100$}

Where, PGI=Per Cent Growth Inhibition, $\mathrm{C}=$ Colony Diameter In Control (mm),

\section{$\mathrm{T}=$ Colony Diameter In Treatment $(\mathrm{mm})$}

\section{Field experiment}

The experiment were carried out at a commercial banana field of "Soil and Water Management Project", situated at Navsari Agricultural University, Navsari, district Navsari of the South Gujarat. Two fungicides viz., carbendazim and propiconazole at minimum inhibitory concentration (MIC) i.e 250 ppm, two phytoextracts viz., garlic clove and cinnamon leaves extract @ 10 per cent and two bioagents viz., Bacillus subtilis and Pseudomonas fluorescens that gave the best inhibition on growth of $L$. theobromae under "in vitro" conditions, were chosen for field evaluation. Carbendazim @ $0.5 \mathrm{gL}^{-1}$, propicanazole @ $1 \mathrm{mlL}^{-1}$ were dissolved in water to get a final concentration of 250 ppm. Garlic clove and cinnamon leaves extract @ $100 \mathrm{mlL}^{-1}$ to get a final concentration of $10 \%$ and bioagents colonies were dissolved in sterile distilled water to get a final concentration $1 \times 107 \mathrm{CFUml}^{-1}$ were used as spray in field. Two cultural practices, covering the bunch after emergence with blue polythene bag $(50 \mu \mathrm{m}$ LLDPE) and green leaves of the same banana plant were also carried out (farmers practice).

There were five plants in each treatment. The plants were thoroughly sprayed before 15 days of harvest. Before the spray the plants were tagged and all dried leaves were removed by cutting. At the time of planting fertilizer dose was given @ 200:90:200 NPK g/ plants to all treated and control plants, plants were irrigated regularly with tube well water. Isolation from the bunches of treated and control plants were made before spray to determine the infection level on each plant. The effect of each treatment on banana bunch was also evaluated by assessing the diseases severity before and after treatment. Disease severity was evaluated with the help of a model proposed for evaluating disease severity of banana fruit rot caused by L. theobromae.

Disease severity of fruit rot was recorded on the basis of 0-5 scales [28] with slightly modification. Where scale $0=$ Fruit completely healthy, $1=$ Symptoms appear only near the crown or tip with a little browning of pericarp portion and fruit completely healthy, $2=<10 \%$ pulp rot with browning of pericarp, $3=10-25 \%$ pulp rot with browning of pericarp, $4=26-50 \%$ pulp rot with browning of pericarp, $5=>50$ percent pulp rot with browning of pericarp and following assessment key (Figure 1a and 1b). Then the rating scales were converted into percent disease index (PDI) for the analysis of disease severity using the following formula.

Per cent disease index $=($ Sum of all numerical ratings $) /($ Total number of fruit examined $\times$ Maximum rating $) \times 100$

Efficacy (E) of each treatment was calculated as under formula:-

$\mathrm{E}(\%)=(\mathrm{PDI}$ of control fruits $-\mathrm{PDI}$ of treated fruits $) /(\mathrm{PDI}$ of control fruits $) \times 100$

Data obtained from the experiments on per cent disease index (PDI) in field and after storage of fruits under natural condition at maturity and eating ripe stage were subjected to statistical analysis.

One hand containing ten fruits were selected from each bunch brought to laboratory kept for ripening under natural condition at room temperature up to full ripening stages. Per cent disease index (PDI) and Efficacy (E) of each treatment were worked out by above mention methods.

\section{Data Analysis:}

The data of respective experiment were analyzed statistically using HLC computer program and means were compared for difference following Analysis of variance (ANOVA).

\section{Results and Discussion}

Différent fungi were successfully isolatéd from different banana fruit rots included, crown portion, rotted pulp, reddish spot on pericarp and dried tip end rot. The mixed infection of $L$. theobromae Pat., F. moniliformae Sheld, Fusarium sp., Aspergillus niger VanTiegh., Acremonium sp. and Curvularia sp. at different stages of field, market and storage was isolated. Among all the isolated fungus, $L$. theobromae pat. was predominantly infected banana fruits being the most virulent, exhibiting pulp rot symptoms. Such isolates and their 
Citation: Nath K, Solanky KU, Kumawat GL (2014) Effective Approaches of Potential Bioagent, Phytoextract, Fungicide and Cultural Practice for Management of Banana Fruit Rot Disease. J Plant Pathol Microb 5: 246. doi:10.4172/2157-7471.1000246

ability to infect banana fruit has been reported by several researchers [8-11] also confirmed that crown rot and fruit rot are the most severe post-harvest disease of banana. It is caused by a complex of fungi with Colletotrichum musae (Berk. and Curt.) being the main pathogen. Additionally, Fusarium moniliformae Sheld., Fusarium pallidoroseum (Cooke) Sacc., Nigrospora sphaerica (Sacc.) Mason and Botryodiplodia theobromae Pat. are implicated with pathogenicity in the Windward Islands.

Cultural and morphological characters of isolated fungus were studied on PDA medium. On the basis of cultural and morphological characters, the isolates were identified as L. theobromae Pat., F. moniliformae Sheld, Fusarium sp., A. niger, Acremonium sp. and Curvularia sp. (Figure 2) with the help of illustrated genera of imperfect fungi [20]. Among these isolates, L. theobromae Pat was frequently isolated and well responsible for finger rot, crown rot and fruit rot disease in field as well as storage condition in South Gujarat region. However, for detail identification the purified cultures were confirmed at Agharkar Research Institute, Pune (No.3/426-2008).

The Lasiodiplodia theobromae Pat. was more prevalent pathogen caused banana fruit rot disease in South Gujarat region, isolated and purified L. theobromae, artificially inoculated on healthy banana (var. Grand naine) fruits and produced similar symptoms of fruit rot (Figure 3) those found in naturally infected fruits. Reisolations from infected inoculated fruits yielded cultures which were identical with the cultures which are used for inoculation of the fruits.

\section{Management of banana fruit rot diseases}

6.1.1 In vitro evaluation of fungicides: The perusal of results presented in Table 1 revealed that all the fungicides tried were
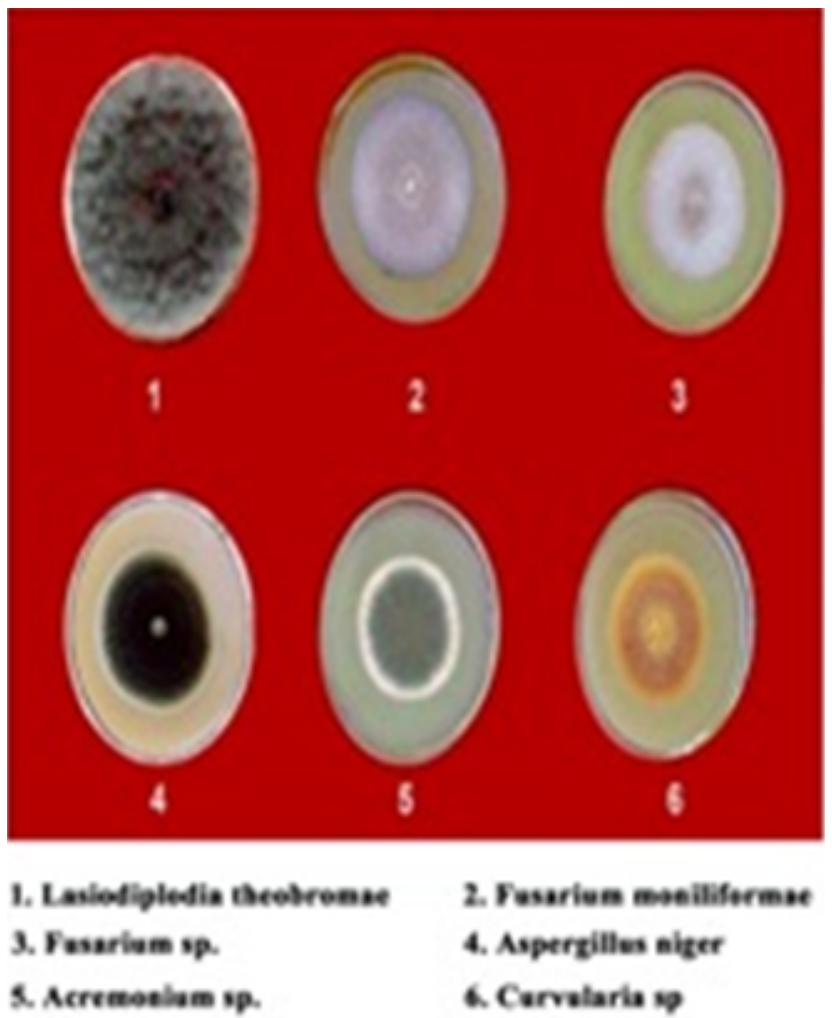

2. Fasuries mosilifermue 4. Asperzilles nizer

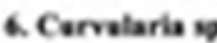

Figure 2: Fungi associated with banana fruit rot.

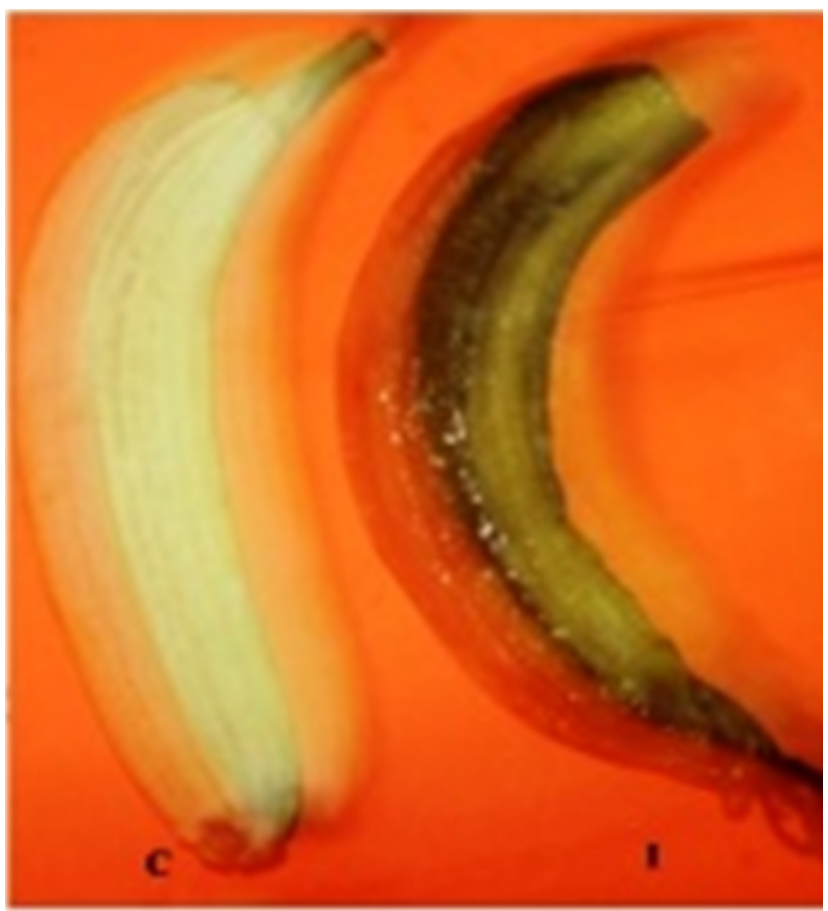

\section{Healthy banens pelp}

\section{I - Banana palp rotted by to L. theabranac.}

Figure 3: Symptoms of banana pulp rot.

inhibitory to the L. theobromae growth except coper oxychloride. Among these systemic fungicide viz., carbendazim and propiconazole at low concentration (@250 ppm),while hexaconazole @ 500 ppm completely inhibited the mycelial growth. But in case of non-systemic fungicide viz., mancozeb and chlothalonil at highest concentration (@2500 ppm) completely inhibited the mycelial growth, while in carbendazim 12\%+mancozeb 63\% at lowest (@1500 ppm) completely inhibited growth after $48 \mathrm{hrs}$ of incubation. Copper oxychloride at lowest (@1500 ppm) stimulated (12.40\%) the fungus growth and it was increased with increased concentration. After $72 \mathrm{hrs}$ of incubation observed that carbendazim and propiconazile at lowest concentration completely inhibited the fungus growth, while hexaconazole at 500 ppm can't completely inhibited the fungus growth that's why the effect of hexaconazole was reduced after $48 \mathrm{hrs}$ of incubation. In nonsystemic fungicide, mancozeb at higher concentration (2500 ppm) completely inhibited the growth of fungus followed by chlorothalonil $(87.59 \%)$, while in case of copper oxychloride the fungus over grew the petri plates i.e. growth was stimulated. Carbendazim $12 \%+$ mancozeb $63 \%$ retained their fungitoxicity up to $72 \mathrm{hrs}$, gave cent percent inhibition. Four fungicides namely, carbendazin and propiconazole at $250 \mathrm{ppm}$ concentration and mancozeb at $2500 \mathrm{ppm}$ and carbendazim $12 \%+$ mancozeb $63 \%$ at $1500 \mathrm{ppm}$ were found superior in completely growth inhibition and proved statistically superior over the rest of tested fungicides, but in case of all tests concentrations for copper oxychloride the pathogen over grew the petri plates i.e. growth was stimulated.

The present result in agreement with dirrefence in inhibitory ability between isolates and fungicides has been earlier reported by Sabalpara [29]. who reported that bavistin and benlate were effective against $B$. 
Citation: Nath K, Solanky KU, Kumawat GL (2014) Effective Approaches of Potential Bioagent, Phytoextract, Fungicide and Cultural Practice for Management of Banana Fruit Rot Disease. J Plant Pathol Microb 5: 246. doi:10.4172/2157-7471.1000246

\begin{tabular}{|c|c|}
\hline Sr. No. & Fungicides \\
\hline 1. & Mancozeb (Dithane M-45 75\%WP) \\
\hline 2. & Copper oxychloride (Blue copper 50 WP) \\
\hline 3. & Chlorothalonil (Kavach 75 WP) \\
\hline 4. & Carbendazim (Bavistin 50 WP) \\
\hline 5. & Propiconazole (Tilt 25\% EC) \\
\hline 6. & Hexaconazole (Contaf 5\% EC) \\
\hline 7. & Carbendazim $12 \%+$ Mancozeb $63 \%$ (SAAF 75 WP) \\
\hline 8. & Control \\
\hline & S.Em. \pm \\
\hline & C.D. at $5 \%$ \\
\hline & C.V.\% \\
\hline
\end{tabular}

*Average of three repetition.

${ }^{* *}$ Figures are $\sqrt{X}+0.5$ transformed values.

${ }^{\star * *}$ Figures are $\sqrt{X}+60$ transformed values

Table 1: In-vitro efficacy of fungicides against mycelial growth of $L$. theobromae.

theobromae, a cause of mango die-back. Thakore [30] found that bavistin $(0.025 \%)$, benlate $(0.025 \%)$, calixin $(0.025 \%)$, dithane M-45 $(0.05 \%)$ and brestanol $(0.2 \%)$ were most effective for the growth inhibition of B. theobromae, a cause of post-harvest rot of sapota. Godara [31] found that bavistin (1000 ppm) completely inhibited fungus growth of Botryodiplodia theobromae. Ahmad et al. [13] observed that benomyl $(0.1 \%)$, captan $(0.2 \%)$, carbendazim $(0.1 \%)$, mancozeb $(0.25 \%)$ and thiophanate-methyl $(0.1 \%)$ were highly fungitoxic to L. theobromae in both solid and liquid media. Banik et. al. [14] reported that complete inhibition of mycelial growth of B. theobromae by carbendazim (400 $\mathrm{ppm})$, followed by captan (450 ppm), thiophanate methyl (450 ppm), ziram $(600 \mathrm{ppm})$ and chlorothalonil $(650 \mathrm{ppm})$ isolated from mango fruit rot disease. Yadav and Majumdar [32] reported effectiveness of carbendazim and mancozeb against $L$. theobromae (Guava isolate). Muhammad et. al. [15] observed significant inhibition of mycelial growth of $L$. theobromae by carbendazim and thiophanate-methyl when used @ 1 ppm a.i. or more. Alliete was effective at relatively higher concentrations i.e., @ 1000 and 10000 ppm a.i., whereas, copxykil, cuprocaffaro and thiovit failed to inhibit the mycelial growth of L. theobromae.

\section{In vitro evaluation of phytoextracts:}

This information is certainly useful in exploiting inhibitory principle for developing botanical fungicides in plant disease management. In the present investigations, unsterilized centrifuged twelve phytoextracts of various plant species at two concentrations were evaluated by poisoned food technique in vitro to know their inhibitory effect on the growth of L. theobromae
Results presented in Table 2 showed that garlic clove and cinnamon leaf extract at all tested concentrations was significant in reducing the mycelial growth. At low concentration, 5\% garlic clove extract caused $17.34 \%$ reduction in mycelial growth, while at $10 \%$ caused $47.09 \%$ mycelial growth reduction. On other hand, cinnamon gave moderate effect in reducing the fungal growth at all tested concentrations by $17.34 \%$ and $33.86 \%$ respectively. The next effective phytoextracts was aloevera leaves extract in order to reduce mycelial growth at all tested concentration by $8.23 \%$ and $16.50 \%$ respectively. Rest of tested phytoextracts showed the mycelial growth stimulation. The highest growth stimulation was observed in lantana, deshi babul and barmasi leaf extracts at $10 \%$ concentration by $75.20 \%, 60.39 \%$ and $45.49 \%$ respectively, while eucalyptus at $5 \%$ concentration by $47.13 \%$ mycelial growth stimulated but at higher concentration (10\%) it declined. Thus, results of our study are in agreement with earlier researchers Sabalpara [29] found significant inhibition of mycelial growth and sporulation of B. theobromae (Mango isolate) by 21 phyto-extracts except eucalyptus. Garlic bulb extract which inhibited the spore germination and mycelial growth of Botryodiplodia theobromae (jute isolate) which is a major seed borne pathogen [33]. Patel [34] found that more than $50 \%$ inhibition of mycelial growth of B. theobromae (Sapota isolate) by garlic clove, turmeric rhizome, garlic leaves and dhatura leaves extracts. Singh et al., [35] evaluated eleven leaf extracts of medicinal plants, the extract from Azadirachta indica and Ocimum sanctum were the most effective in inhibiting the mycelia growth of B. theobromae, Fusarium oxysporum, Helminthosporium speciferum, Curvularia lunata, Aspergillus flavus and Trichothecium roseum. Aqueous garlic 


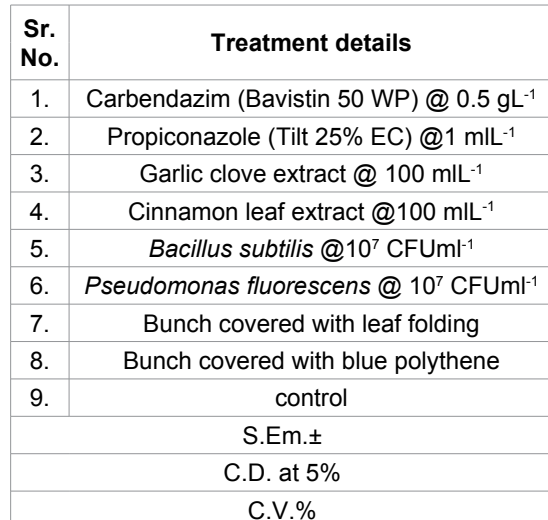

to cause maximum inhibition to mycelial growth of $L$. theobromae under laboratory conditions was chosen for field evaluation.

\section{Field experiment}

The results presented in Table 4 reveal that all the treatments significantly reduced finger rot disease in field experiment. The reduction of finger rot was cent percent with Carbendazim @ $0.5 \mathrm{gL}^{-1}$, Propiconazole@1 mlL ${ }^{-1}$, Garlic clove and Cinnamon leaf extract @ 100 $\mathrm{mlL}^{-1}$ followed by Bacillus subtilis @1×107 CFU (92.71\%) and bunch covered with blue polythene bag (80.89\%) when compared to control. It was also observed that the bunches treated with propiconazole showed prolonged maturity of fruits as compared to other treatments. In untreated (control) bunches, per cent disease index increased with increase in time. None of the treatments exhibited phytotoxic effect on fruits under the field conditions.

One hand having ten fruits were selected from each bunch brought to the laboratory kept for ripening under natural condition at room temperature up to full ripening stage and allowed disease to develop on it. Evaluation of each treatment was done with help of per cent fruit area infected under assessment key, described in material and methods. All fruits assessments were made at the eating ripe stage, the results presented in Table 5 revealed that all the treatments significantly reduced per cent disease index except bunch covered with grown leaf folded. Propiconazole @ $1 \mathrm{mlL}^{-1}$ treated bunch was found to be most effective in completely checking fruit rot disease under

\begin{tabular}{|l|l|c|}
\hline $\begin{array}{c}\text { Sr. } \\
\text { No. }\end{array}$ & \multicolumn{1}{|c|}{ Bio-control agents } & $\begin{array}{c}\text { Mycelial growth } \\
\text { inhibition (\%) }\end{array}$ \\
\hline 1. & Trichoderma viride Pers (IARI, New Delhi, isolate) & $31.39(34.38)^{* *}$ \\
\hline 2. & Trichoderma harzianum Rifai (Junagadh, Gujarat, isolate) & $47.50(43.56)$ \\
\hline 3. & $\begin{array}{l}\text { Trichoderma longibrachyatum Rifai (IARI, New Delhi, } \\
\text { isolate) }\end{array}$ & $61.25(51.50)$ \\
\hline 4. & Bacillus subtilis (Anand, Gujarat, isolate) & $70.56(57.37)$ \\
\hline 5. & Pseudomonas fluorescens (Junagadh, Gujarat, isolate) & $75.83(60.55)$ \\
\hline 6. & Control & $0.00(4.05)$ \\
\hline & S.Em. \pm & 0.028 \\
\hline & C.D. at 5\% & 0.083 \\
\hline & C.V.\% & 0.86 \\
\hline
\end{tabular}

${ }^{*}$ Average of three repetition.

${ }^{* *}$ Figures in parentheses are angular transformed $(X+0.5)$ values

Table 3: In-vitro evaluation of bio-control agents on mycelial growth of L. theobromae by dual culture.

which showed moderate antagonism. Pseudomonas fluorescens an Bacillus subtilis have showed good antagonism against pathogen. The inhibiting capacity of isolates was directly correlated with the faster growth rate of antagonist. Thus, results of our study are more or less corroborate with the results of earlier workers Florence and Sharma [17] found that Bacillus subtilis can be used as potential bio-control agent against the B. theobromae. Aranguren et al. [36] tested antagonistic potentials of different Trichodaerma spp. against B. theobromae and achieved the highest inhibition with T. longibrachyatum and T. viride. Gupta et al. [37] studied in vitro mycoparasitic activity of various bio-agents against B. theobromae and concluded that T. viride, T. harzianum and T. pseudokoningii inhibited growth of B. theobromae. Mortuza and Ilag [38] observed that Trichoderma harzianum exhibited the maximum growth inhibition of $L$. theobromae in dual culture. Alvindia and Natsuaki [18] reported that Bacillus amyloliquefaciens DGA14 inhibited all test crown rot pathogens namely $L$. theobromae, Thielaviopsis paradoxa, Colletotrichum musae, and Fusarium verticillioides in culture. Post-harvest application of B. amyloliquefaciens DGA14 in the packing house reduced the incidence of crown rot to a lower level than in fungicidal treatment. The biocontrol agents of Pseudomonas fluorescens and Bacillus subtilis found

\begin{tabular}{|c|c|c|c|}
\hline \multirow{2}{*}{$\begin{array}{l}\text { Sr. } \\
\text { No. }\end{array}$} & \multirow{2}{*}{ Treatment details } & \multicolumn{2}{|c|}{ Disease development } \\
\hline & & PDI $^{* *}$ & Inhibition (\%) \\
\hline 1. & Carbendazim (Bavistin 50 WP) @ $0.5 \mathrm{gL}^{-1}$ & $0.00(4.05)^{*}$ & $100.00(90.0)$ \\
\hline 2. & Propiconazole (Tilt 25\% EC) @1 $\mathrm{mlL}^{-1}$ & $0.00(4.05)$ & $100.00(90.0)$ \\
\hline 3. & Garlic clove extract @ $100 \mathrm{mlL}^{-1}$ & $0.00(4.05)$ & $100.00(90.0)$ \\
\hline 4. & Cinnamon leaf extract @100 mlL-1 & $0.00(4.05)$ & $100.00(90.0)$ \\
\hline 5. & Bacillus subtilis @1 x 107 CFU/ml & $0.18(4.73)$ & $92.71(74.89)$ \\
\hline 6. & Pseudomonas fluorescens @ 1 x 107 CFU/ml & $0.33(5.23)$ & $84.53(67.24)$ \\
\hline 7. & Bunch covered by folding grown leaf & $1.17(7.50)$ & $42.21(40.80)$ \\
\hline 8. & Bunch covered with blue LLDPE bags & $0.39(5.41)$ & $80.89(64.44)$ \\
\hline 9. & control & $2.05(9.19)$ & $0.00(4.05)$ \\
\hline & S.Em. \pm & 0.06 & 0.34 \\
\hline & C.D. at $5 \%$ & 0.18 & 1.02 \\
\hline & C.V.\% & 11.41 & 7.06 \\
\hline
\end{tabular}

${ }^{*}$ Figures in the parentheses are angular transformed values. ${ }^{* *}$ Average of three replication.

Table 4: Effect of potential bioagents, phytoextracts, fungicides and cultural practices of disease management approaches on banana fruit rot under field conditions. 
Citation: Nath K, Solanky KU, Kumawat GL (2014) Effective Approaches of Potential Bioagent, Phytoextract, Fungicide and Cultural Practice for Management of Banana Fruit Rot Disease. J Plant Pathol Microb 5: 246. doi:10.4172/2157-7471.1000246

\begin{tabular}{|c|c|c|c|c|c|c|c|}
\hline \multirow{2}{*}{$\begin{array}{l}\text { Sr. } \\
\text { No. }\end{array}$} & \multirow{2}{*}{$\begin{array}{l}\text { Common name } \\
\text { of Phytoextracts }\end{array}$} & \multirow{2}{*}{$\begin{array}{c}\text { Plant part } \\
\text { used }\end{array}$} & \multirow{2}{*}{$\begin{array}{c}\text { Conc. } \\
(\%)\end{array}$} & \multicolumn{4}{|c|}{ Growth after $48 \mathrm{hrs}$ of incubation } \\
\hline & & & & Grow & $h(m m) *$ & Inhibi & on $(\%)$ \\
\hline \multirow[t]{2}{*}{1.} & \multirow{2}{*}{$\begin{array}{c}\text { Acalypha } \\
\text { (Acalypha indica } \\
\text { L.) }\end{array}$} & \multirow{2}{*}{ Leaves } & 5 & \multicolumn{2}{|c|}{$45.67(6.79)$ ** } & \multicolumn{2}{|c|}{$-13.25(8.20)^{* * *}$} \\
\hline & & & 10 & \multicolumn{2}{|c|}{$52.67(7.29)$} & \multicolumn{2}{|c|}{$-30.59(7.06)$} \\
\hline \multirow{2}{*}{2.} & \multirow{2}{*}{$\begin{array}{l}\text { Barmasi } \\
\text { (Catharanthus } \\
\text { roseus L.) }\end{array}$} & \multirow{2}{*}{ Leaves } & 5 & \multicolumn{2}{|c|}{$53.67(7.36)$} & \multicolumn{2}{|c|}{$-33.07(6.88)$} \\
\hline & & & 10 & \multicolumn{2}{|c|}{$58.67(7.69)$} & \multicolumn{2}{|c|}{$-45.49(5.91)$} \\
\hline \multirow[b]{2}{*}{3.} & \multirow{2}{*}{$\begin{array}{l}\text { Garlic (Allium } \\
\text { sativum L.) }\end{array}$} & \multirow[b]{2}{*}{ cloves } & 5 & \multicolumn{2}{|c|}{$33.33(5.82)$} & \multicolumn{2}{|c|}{$17.34(9.89)$} \\
\hline & & & 10 & \multicolumn{2}{|c|}{$21.33(4.67)$} & \multicolumn{2}{|c|}{$47.09(11.30)$} \\
\hline \multirow[b]{2}{*}{4.} & \multirow{2}{*}{$\begin{array}{c}\text { Turmeric } \\
\text { (Curcuma longa } \\
\text { L.) }\end{array}$} & \multirow[b]{2}{*}{ Rhizomes } & 5 & 42.3 & $3(6.44)$ & -4.95 & (8.69) \\
\hline & & & 10 & 46.6 & $(6.87)$ & -15.7 & (8.05) \\
\hline 5 & Lantana (Lantana & I & 5 & 54.6 & $7(7.43)$ & -35.5 & $(6.70)$ \\
\hline 5. & camara L.) & Leaves & 10 & 70.6 & $(8.44)$ & -75.2 & $(2.30)$ \\
\hline & Neem & & 5 & 46.3 & $3(6.84)$ & -14.9 & $(8.10)$ \\
\hline 6. & $\begin{array}{l}\text { (Azadirachta } \\
\text { indica Juss.) }\end{array}$ & Leaves & 10 & 48.6 & $(7.01)$ & -20.6 & (7.73) \\
\hline & Black Tulsi & & 5 & 45.6 & (6.79) & -13.2 & $(8.20)$ \\
\hline 7. & $\begin{array}{c}\text { (Ocimum } \\
\text { basilcum L.) }\end{array}$ & Leaves & 10 & 56.6 & $(7.56)$ & -40.4 & (6.23) \\
\hline 8 & Babul (Acacia & Lon & 5 & 54.6 & $(7.42)$ & -35.6 & (6.64) \\
\hline 8. & nilotica L.) & Lea & 10 & 64.6 & (8.02) & -60.3 & $(4.45)$ \\
\hline & Eucalyptus & & 5 & 59.3 & $3(7.73)$ & -47.1 & $(5.77)$ \\
\hline 9. & $\begin{array}{c}\text { (Eucalyptus } \\
\text { citriodora Hoch.) }\end{array}$ & Leaves & 10 & 51.3 & $3(7.20)$ & -27.3 & (7.30) \\
\hline 10 & Aloevera (Aloe & 10 & 5 & 37.0 & $(6.12)$ & 8.23 & $9.42)$ \\
\hline 10. & barbadensis L.) & Leaves & 10 & 33.6 & (5.84) & 16.5 & (9.85) \\
\hline & Cinnamon & & 5 & 33.3 & $3(5.82)$ & 17.3 & (9.89) \\
\hline 11. & $\begin{array}{l}\text { (Cinnamomum } \\
\text { zeylanicum L.) }\end{array}$ & Leaves & 10 & 26.6 & $(5.21)$ & 33.86 & 10.70) \\
\hline 12 & Ardusi (Adhatoda & I0 & 5 & 50.6 & $(7.16)$ & -25.6 & $(7.40)$ \\
\hline 12. & vasica Ness.) & Leaves & 10 & 57.3 & $3(7.60)$ & -42.1 & $(6.20)$ \\
\hline & Control & & - & 40.3 & $3(6.39)$ & & \\
\hline & & & & S.Emt & $\begin{array}{l}\text { C.D. at } \\
5 \%\end{array}$ & S.Em. \pm & $\begin{array}{l}\text { C.D. at } \\
5 \%\end{array}$ \\
\hline & Treatment & & & 0.04 & 0.12 & 0.12 & 0.35 \\
\hline & Concentration & & & 0.02 & 0.047 & 0.05 & 0.15 \\
\hline & $\begin{array}{c}\text { Treatment X } \\
\text { Concentration }\end{array}$ & & & 0.06 & 0.16 & 0.18 & 0.50 \\
\hline & C.V.\% & & & 1.4 & & & \\
\hline
\end{tabular}

${ }^{*}$ Average of three repetition.

${ }^{* *}$ Figures are $\sqrt{X}+0.5$ transformed values.

${ }^{* * *}$ Figures are $\sqrt{X+80}$ transformed values.

Table 5: In vitro bio-efficacy of phytoextracts on mycelial growth of $L$. theobromae.

storage conditions up to eating ripe stage followed by Carbendazim (94.12\%),Cinnamon leave extracts (91.48\%),bunch covered with blue polythene bag (87.32\%) and Garlic clove extract (83.07\%). In another study by Bedimo et al. [19], confirmed control of banana anthracnose (Colletotrichum musae) through deflowering and bunch covering at horizontal fingers stage. Win et al. [39] found that disease development was least ( 25 per cent) on cinnamon extract (@ $\left.5 \mathrm{mlL}^{-1}\right)$, treated fruit after inoculation of crown rot pathogen (Colletotrichum musae, Fusarium spp. Lasiodiplodia theobromae) compared to carbendazim (@0.75 g/lit).

From the present results it is clear that preharvest treatment reduced the infecting propagules of the fruit rot pathogens there by reducing the post-harvest decay. Bacillus subtilis reduced fruit rot development under storage conditions as compared to field condition because it requires time and suitable condition for colonization on fruit surface in field condition which was less as compared to storage condition. Antagonist also enhanced defence related enzyme activity.
In case of bunch covered with blue polythene bag directly reduced the inoculum which is carried to storage condition, resulting in to less fruit rot disease.

\section{Summary and Conclusion}

Banana fruit rot is an emerging disease caused by L. theobromae in South Gujarat region. Carbendazim @ $0.5 \mathrm{gL}^{-1}$, propiconazole @ 1 $\mathrm{mlL}^{-1}$, garlic and cinnamon @ $100 \mathrm{mlL}^{-1}$ gave cent per cent control of finger rot disease followed by Bacillus subtilis $1 \times 107$ CFU (92.71\%). However, the plants sprayed with propiconazole exhibited delayed fruit maturity. None of the treatment elicited any phytotoxic response under the field conditions. In pre harvest treated banana fruits kept for natural ripening Propiconazole @ $1 \mathrm{mlL}^{-1}$ treated banana fruits gave cent per cent fruit rot disease control followed by Carbendazim @ $0.5 \mathrm{gL}^{-1}(94.12 \%)$, Cinnamon leaf extracts (91.48\%), Garlic clove extract $(83.07 \%)$, Carbendazim $(94.12 \%)$ and bunch covered with blue polythene bag $(87.32 \%)$ under storage condition. The success of application could be attributed to establishment and rapid buildup of bio-control agents in the fruit surface which, could have assisted in reducing the infectivity of air borne inoculum. Application as field spray would prevent proliferation of air borne inoculums. This is relevant for fruit rot pathogen such as $L$. theobromae where postharvest treatment with chemicals can retain toxic effect. Bunch covered with blue polythene bag directly reduced the inoculums which resulted in less disease under storage condition.

The results of present study showed that the possibility of integrated disease management components such as fungicides i.e. carbendazim and propiconazole, biocontrol agents i.e. Pseudomonas fluorescens and Bacillus subtilis and farmers practices i.e. bunch covered with blue polythene bag and bunch covered with grown leaf reduced fiels as well as post-harvest disease severity of banana fruit rot induced by L. theobromae. So such phytoextracts, bio-control agents and bunch covered with blue polythene bag can be used as a potential source of sustainable eco-friendly integrated disease management practices.

\section{Acknowledgments}

The expert technical contributions of Dr. K.U. Solanky and Dr. Mahesh Kumar Mahatma are gratefully acknowledged. We acknowledged to Department of Plant Pathology, N. M. College of Agriculture, Navsari Agricultural University, Navsari, for providing technical assistance. We would like to thank to Dr. R.G. Patil, Research Scientist, Soil and Water Management Research Station, N.A.U, Navsari for providing experimental field and Department of Statistic for statistical analyses.

\section{References}

1. FAO (2013) Climatic Database.

2. NHB (2013) Horticulture data base, 34-44

3. Kachhwaha M, Chile A Khare V, Mehta A, Mehta P (1991) A new fruit rot disease of Banana. Indian Phytopathology 22, 211.

4. Goos RD, Cox EA, Stotsky G (1961) Botryodiplodia theobromae and its association with Musa species. Mycologia 53: 262-277.

5. Wade NL, Kavanagh EE, Sepiah M (1993) Effects of modified atmosphere storage on banana postharvest diseases and the control of bunch main-stalk rot. Postharvest Biology and Technology 3-143-154.

6. Ploetz R (1998) Banana disease in the subtropics: a review of their impoatance distribution and management. Acta Horti. 490: 263-276.

7. Khanzada MA, Lodhi AM and Shahzad S (2004b) Pathogenicity of Lasiodiplodia theobromae and Fusarium solani on mango. Pak. J. Bot. 36: 181-189.

8. Griffee PJ, Burden OJ (1976) Fungi associated with crown rot of boxed bananas in the Windward Islands. Phytopathol 85: 149-158.

9. Wallbridge A (1981) Fungi associated with crown-rot disease of boxed bananas 
Citation: Nath K, Solanky KU, Kumawat GL (2014) Effective Approaches of Potential Bioagent, Phytoextract, Fungicide and Cultural Practice for Management of Banana Fruit Rot Disease. J Plant Pathol Microb 5: 246. doi:10.4172/2157-7471.1000246

from the Windward Islands during a two year survey. Trans. Br. Mycol. Soc. 77: 567-577.

10. Finlay AR, Brown AE (1993) The relative importance of Colletotrichum musae as a crown-rot pathogen on Windward Island bananas. Plant Pathol. 42: 67-74

11. Johanson A, Blazquez B (1992) Fungi associated with banana crown rot on field packed fruit from the Windward Island and assessment of their sensitivity to the fungicides thiabendazole, prochloraz and imazalil. Crop Protc. 11: 79-83.

12. Punithalingam E (1980) Plant diseases attributed to Botryodiplodia theobromae Pat.J.Cramer, Vaduz, 42-43.

13. Ahmed I, Mahmood A, Majeed, Saleem A (1995) Evaluation of various fungicides against die-back disease caused by Diplodia natalensis in mango. Pak. J. Phytopathol. 7: 208-209.

14. Banik AK, SI Kaiser KM, Dhua RS (1998) Evaluation of some systemic and non systemic fungicides against Botryodiplodia theobromae, the cause of dieback disease of mango. J. Soil \& Crops, 8: 199-222.

15. Muhammad AK, Lodhi AM, Saleem S (2005) Chemical control of Lasiodiplodia theobromae the causal agent of mango decline in Sindh. Pak. J. Bot. 37: 10231030

16. Andrade LGS, Lima NMF, Lopez AMQ (1996) Effect of aqueous extracts from garlic bulbs (Allium Sativum) on germination and mycelial growth of Botryodiplodia theobromae Pat. In vitro. Ciencia Agricola, 4: 7-15.

17. Florence EJM, Sharma JK (1990) Botryodiplodia theobromae associated with blue staining in commercially important timbers of Kerala and its possible biological control. Material-und-organismen 25: 193-199.

18. Alvindia DG, Natsuaki KT (2009) Biocontrol activities of Bacillus amyloliquefaciens DGA14 isolated from banana fruit surface against banana crown rot-causing pathogens. Crop Protection, 28: 236-242.

19. Bedimo JM, Chittet M, Jullien A, Lapeyre D, Bellaire LD (2003) The early bunch covering of banana improves the growth of fruit and it sanitary state with respect to anthracnosis (Colletotrichum musae). Review of Plant Pathology 82: 972.

20. Barnett HL, Hunters BB (1985) Illustrated Genera of Imperfect Fungi. 4th Ed., Macmillan Incorporation, 201.

21. Nene YL, Thapliya AS (1993) Fungicides in plant disease control, Oxford and IBH Publishing Co. Pvt. Ltd., New Delhi, 525-540.

22. Bliss CA (1934) The method of probits analysis. Science, 79, 39.

23. Shekhawat PS and Prasad R (1971) Antifungal properties of some plan extracts on inhibition of spore germination. Indian Phytopath. 24: 800-802.

24. Schemitz, H. (1930) Poisoned Food Technique. Indust. Engin. Chem. Analyst., 361.

25. Vincent JM (1947) Distortion of fungal hyphae in presence of certain inhibitors. Nature 159: 850
26. Dennis C, Webster J (1971) Antagonistic properties of special groups of Trichoderma III, Hyphal intera-ction. Trans. Britis Mycol. Sci, 57: 363-369.

27. Asalmol MN, Sen B, Awasti J (1990) Role of temperature, pH in antagonism of Aspergillus niger and T. viride against F. solani proc. Indian Phyto. Pathol. Soc. on biocontrol of Plant Pathogen. pp. 11-13.

28. Rose DH (1974) Diseases of apple fruits in the market. Bull. US. Dep. Agric. 1253:24.

29. Sabalpara AN (1983) Investigations regarding twig blight and die-back disease of mango caused by Botryodiplodia theobromae Pat. M. Sc. (Agri.) thesis, G.A.U., Sardar Krishinagar.

30. Thakore RA (1983) Studies on post-harvest disease of sapota (Achras sapota L.) occurring in South Gujarat and their control. M. Sc. (Agri.) thesis, G.A.U. Sardar Krishinagar.

31. Godara SL (1994) Studies on post-harvest disease of orange fruits. Ph.D. Thesis (Unpublished), Submitted to Rajasthan Agricultural University Campus, Udaipur.

32. Yadav RK, Majumdar VL (2004) Efficacy of plant extracts, biological agents and fungicides against Lasiodiplodia theobrome incited die back of guava (Psidium guajava). J. Mycol. PI. Pathol. 34: 415-417.

33. Ahemad N and Sultana K (1984) Fungitoxic effect of garlic on treatment of jute seeds. Bangladesh J. Bot. 13: 130-136.

34. Patel PB (1989) Investigations on twig blight (Botryodiplodia theobromae) and occurrence of sapota (Achras sapota L.) disease in South Gujarat M. Sc. (Agri.) thesis, G.A.U., Sardar Krishinagar (Unpublished).

35. Singh HNP, Prasad MM, Sinha KK (1993) Efficacy of leaf extracts of some medicinal plants against disease development in banana. Lett. Appl. Microbiol. 17: 269-271.

36. Aranguren M, Garcia A and Grillo H (1994) In vitro evaluation of three isolates of Trichoderma antagonists of post harvest pathogens of citrus fruits. Centro Agricola, 21: 42-45.

37. Gupta VP, Tewar SK, Govidaiah and Bajpai AK (1999) Ultra structure of mycoparasitisms of Trichoderma, Gliocladium and Laetisaria species on Botryodiplodia theobromae. J. Phytopathogy 147: 19-24.

38. Mortuza MG and llag LL (1999) Potential for biocontrol of Lasiodiplodia theobromae (Pat.) Griff. \& Maubl. in banana fruits by Trichoderma Species. Biological Control 15: 235-240.

39. Win NKK, Jitareerat P, Kanlayanarat S, Sangchote S (2007) Effects of cinnamon extract, chitosan coating, hot water treatment and their combinations on crown rot disease and quality of banana fruits. Review of Plant Pathology 86: 1546. 